A Research Report for the Rockwell Hanford Operations

\title{
Revegetation of a Waste Disposal Site in the 200 Areas of the Hanford Reservation
}

by

J. F. Cline

V. A. Uresk

November 1977

Prepared for the

U.S. Department of Energy 


\title{
NOTICE
}

This report was prepared as an account of work sponsored by the United States Covernment. Neither the United States nor the Department of Energy, nor any of their employees, nor any of their contractors, subcontractors, of their-employėes, makes any warranty, express or implied, or assumes any legal liability or responsibility for the accuracy, compleseness or usefuiness of any information, apparatus, product or process disclosed, or represents that its use would not infringe privately owned rights.

The views, opinions and conclusions contained in this report are those of the contractor and do not necessarily represent those of the United States Covernment or the United States Department of Energy.

\author{
PACIFIC NORTHWIEST LABORATORY \\ operated by \\ BATTELLE \\ for the \\ UNITED STATES DEPARTMENT OF ENERGY \\ Under Contract EY-76-C-06-1830
}

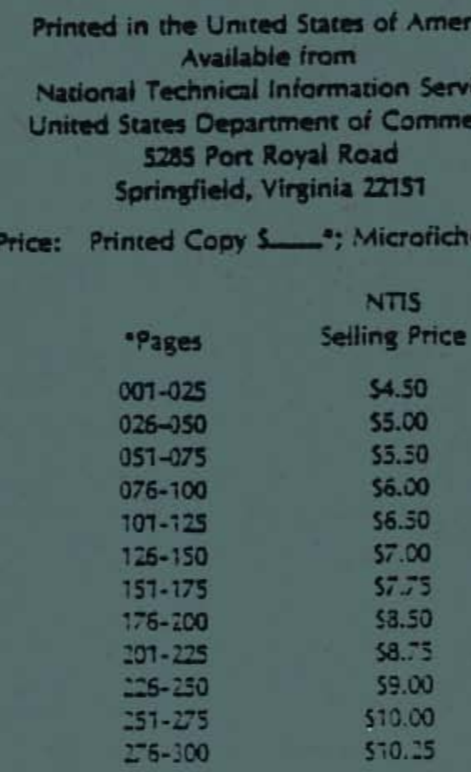




\begin{abstract}
A Research Report for the Rockwell Hanford Operations
\end{abstract}

\title{
Revegetation of a Waste Disposal Site in the 200 Areas of the Hanford Reservation
}

by

J. F. Cline

V. A. Uresk

November 1977

Battelle

Pacific Northwest Laboratories

Richland, Washington 99352 


\section{ACKNOWLEDGMENT}

This Department of Energy study was made possible jointly by the Rockwel1 Hanford Operations (RHO) and by the Division of Biological and Environmental Research (DBER) using Department of Energy funds. Studies on botanical characteristics and the agronomic behavior of grasses chosen for this revegetation effort were developed on the Arid Land Ecology Reserve under DBER funding. Specific application of these principles and their test in a waste management situation were made possible by RHO funding. 


\section{CONTENTS}

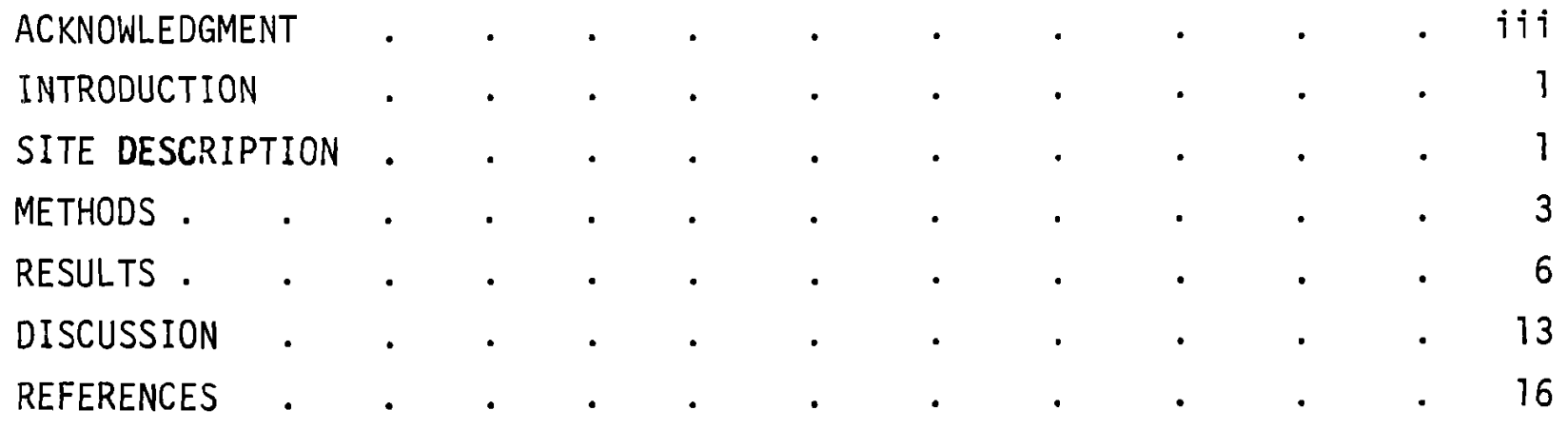




\section{FIGURES}

1 The Location of the Revegetation Site in the 200 West Area . . 2

2 Experimental Design of the Revegetation Plots . . . . 4

3 Mound of Soil in Centimeters that was Deposited on the

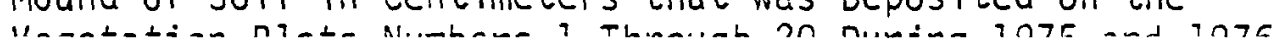

communities. At the lower elevation of the waste management areas a sagebrush/cheatgrass-sandberg bluegrass community is dominant. Big sagebrush, bitterbrush, rabbitbrush, balsamroot, tumble mustard and cheatgrass are the major species (Cline et al., 1977).

The study area designated as Test Plots in Figure 1 is located on a portion of a former 17-acre cooling water pond, known as the 216-5-17 or Redox Pond. This pond was used from October 1951 to April 1954 to receive process vessel cooling water and steam condensate arising from operation of the Redox plant (202-S), (BNWL MA-88).

The approximate inventory of radionuclides in the pond sediments as calculated from discharge data is presented in Table 1.

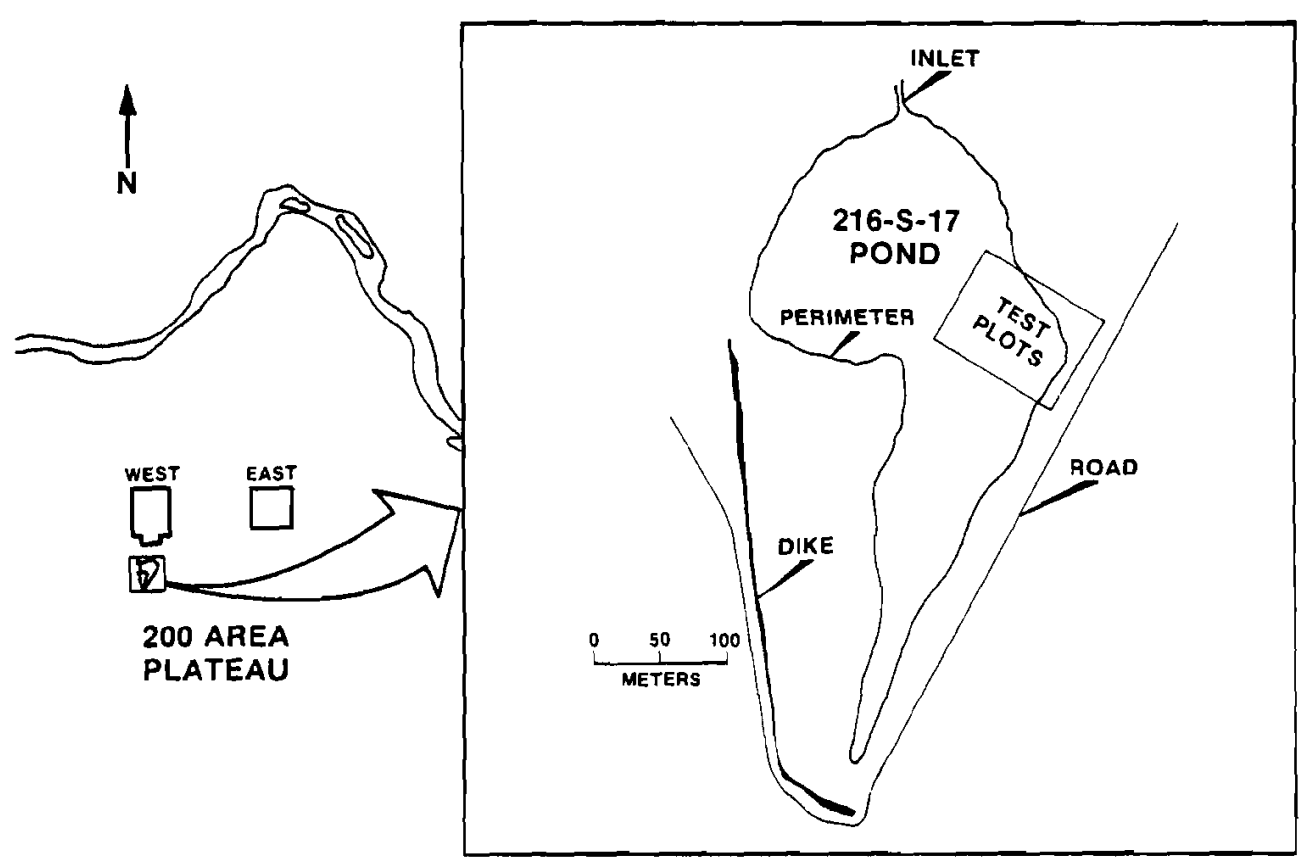

FIGURE 1. The Location of the Revegetation Site in the 200 West Area 
TABLE 1. Radionuclide content in 216-5-17 Pond (a) (BNWL MA-88)

\begin{tabular}{lcc} 
& $\begin{array}{c}\text { At time of } \\
\text { discharge }\end{array}$ & $\begin{array}{c}\text { Decayed to } \\
1976\end{array}$ \\
\cline { 2 - 2 } Beta (Ci) & 1100 & 78.5 \\
Sr-90 (Ci) & 40 & 22.3 \\
Ru-106 (Ci) & 50 & $4.1 \times 10^{-5}$ \\
Cs-137 (Ci) & 30 & 17.4 \\
U (kg) & 136 & 136 \\
Pu (g) & 3.0 & 3.0
\end{tabular}

(a) Calculated from discharge data

In April 1954 the pond was taken out of service when an inadvertent release of fission products caused the radionuclide concentrations in the pond sediments to exceed prescribed disposal limits. At that time the pipeline to the pond north of the 216-S-5 crib was plugged and the pond was allowed to dry out. The pond then was covered with noncontaminated soil fill to prevent the spread of contamination by wind. Approximately $1.06 \mathrm{~m}$ of soil was added to the main pond and 0.5-0.6 $\mathrm{m}$ to the remaining sections (Maxfield, 1977). No stabilization of the area was attempted at that time. Subsequently wind erosion was responsible for blowing away several $\mathrm{cm}$ of soil fill. Russian thistles (Salsola kali) and bursage (Ambrosia acanthicarpa) became self-established in the area and in the shallow soil fill areas their roots penetrated the contaminated layer resulting in accumulation of nuisance quantities of ${ }^{90} \mathrm{Sr}$ and ${ }^{137} \mathrm{Cs}$ in plant tissues.

\section{METHODS}

In the fall of $19740.9 \mathrm{~m}$ of additional soil fill was added to about 4 ha of the site supporting the greatest number of contaminated Russian thistle. A 0.9 ha portion of this clean soil fill was used for establishment of a revegetation test area. The soil fill was wetted and compacted during the hauling process to reduce erosion and settling and to provide a moist 
environment to encourage seed germination. The study area was then staked and divided into 20 plots each measuring $20 \mathrm{~m} \times 20 \mathrm{~m}$. The plots were arranged in a block 5 plots by 4 plots wide.

Four soil treatments were chosen for the randomized block designed experiment. These consisted of a control and soil amendments of bentonite clay, straw, and a straw/clay mixture. Each treatment was replicated five times and placed randomly throughout the 20 plots (Figure 2).

Fifteen hundred $\mathrm{kg}$ of Wyoming bentonite clay was placed on each of 10 of the 20 plots. Farm disc machinery was used to mix the clay into the top $15 \mathrm{~cm}$ of soil. One-hundred ninety $\mathrm{kg}$ of rye straw per plot was disced into each of 10 plots. The straw was disced into 5 of the plots previously treated with clay to create the straw/clay treatment. Care was taken during discing to leave approximately half of the straw length extended vertically above the ground surface to form a wind friction barrier to reduce wind velocity at ground

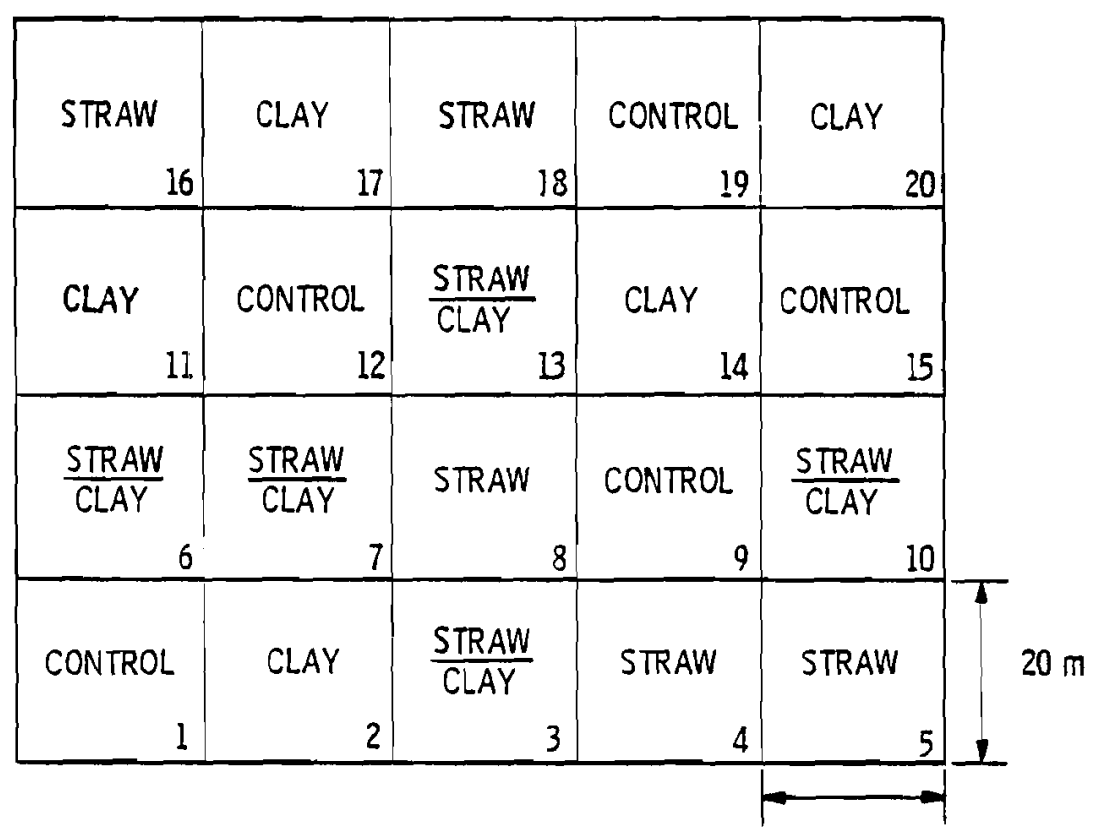

$20 \mathrm{~m}$

FIGURE 2. Experimental Design of the Revegetation Plots 
level. The 5 control plots remained untreated. A11 20 plots were fertilized with a total of $540 \mathrm{~kg}$ of commercial fertilizer $\left(\mathrm{NH}_{4} \mathrm{NO}_{3}\right)$. After all the treatments and fertilizer were disced into the soil, $45 \mathrm{~kg}$ of cheatgrass (Bromus tectorum) seed was broadcast evenly over all of the plots. Then 34,090 e of water were sprinkled over the plots using a water truck.

The planting was completed November 11, 1974. Germination of the cheatgrass was observed at the end of November and a good stand of cheatgrass and limited volunteer rye crop from the straw mulch was measured during the 1975 growing season.

During the 1975, 1976 and 1977 growing seasons percent frequency of occurrence and cover of various species of plants were measured using the method described by Daubenmire (1959). Biomass was measured in 1975 by clipping all the vegetation at maturity within a $0.1 \mathrm{~m}^{2}$ quadrat from each plot. The plant samples were oven dried at $50^{\circ} \mathrm{C}$, weighed and analyzed for total nitrogen, phosphorus and potassium content.

Following the 1976 and 1977 growing seasons the volumes (length $x$ width $x$ height) of mature Russian thistle plants on each plot were determined. The plants touching a line-transect through the middle of each plot were measured.

Mature Russian thistle plant tissue was analyzed for ${ }^{90} \mathrm{Sr}$ content following the 1976 growing season. Plants were harvested from each plot, oven dried and taken to U.S. Testing Company for ${ }^{90}$ Sr determination (HW-81277).

Black-tailed hares were observed foraging on the plots during the spring months. To determine what plants they were eating, their fecal pellets were collected from a meter-wide strip down the middle of each plot during the growing season. The pellets were submitted for dietary analys is using the microscopic technique described by Rogers and Uresk (1974).

Several violent wind storms during the 1975-1976 season caused considerable erosion from adjacent disturbed ground on the windward side of the test area. This resulted in the deposition of significant amounts of soil on several of the test plots. The amount of soil deposited was determined by measuring the depth of sand over the plant crowns from the previous growing season. 


\section{RESULTS}

The percent frequency of occurrence of cheatgrass in sample plots was $>80 \%$ in the control and straw treated plots and $>90 \%$ in the straw/clay and clay treated plots during the first (1975) growing season (Table 2). The percent frequency increased to $295 \%$ during the second year (1976) in all the plots regardless of treatment. However, in 1977 only a few cheatgrass plants were present, because only a few seeds germinated in the fall of 1976, a period of less than $5 \mathrm{~cm}$ of precipitation.

Rye (Secale cereale) occurred in the straw and straw/clay treated plots in the 1975 and 1976 seasons, but was not observed in the plots in 1977 .

Russian thistle occurred in all the plots, and the percent frequency increased each year from $\geq 50 \%$ in 1975 to $\geq 80 \%$ in 1976 to $\geq 96 \%$ in 1977 (Table 2). The one exception is the higher percent frequency of occurrence (83\%) in the straw/clay plot in 1975. Two other species, bursage (Ambrosia acanthicarpa) and Tansy mustard (Descurainia pinnata) were observed in the plots. The results show frequency of occurrence from 0 to $24 \%$ with no effect from plot treatment.

TABLE 2. Percent Frequency of Occurrence for Three Growing Seasons - 1975, 1976 and 1977

\begin{tabular}{|c|c|c|c|c|c|c|c|c|c|c|c|c|}
\hline \multirow[b]{2}{*}{ Species } & \multicolumn{3}{|c|}{ Control } & \multicolumn{3}{|c|}{ Straw } & \multicolumn{3}{|c|}{ Straw/Clay } & \multicolumn{3}{|c|}{ Clay } \\
\hline & 1975 & 1976 & 1977 & 1975 & 1976 & 1977 & 1975 & 1976 & 1977 & 1975 & 1976 & 1977 \\
\hline Cheatgrass & 84 & 96 & 3 & 87 & 95 & 4 & 98 & 96 & 0 & 90 & 99 & 0 \\
\hline Rye & 0 & 2 & & 60 & 22 & 0 & 53 & 12 & 0 & 0 & 0 & 0 \\
\hline Russian Thistle & 51 & 90 & 98 & 60 & 89 & 99 & 83 & 84 & 98 & 58 & 87 & 96 \\
\hline Bursage & 11 & 5 & 8 & 10 & 0 & 7 & 9 & 5 & 7 & 7 & 11 & 4 \\
\hline Tansy Mustard & 0 & 24 & 4 & 0 & 43 & 5 & 0 & 21 & 0 & 0 & 24 & 1 \\
\hline
\end{tabular}


The straw, clay and straw/clay treated plots had similar cover by cheatgrass with less cover on the control plots (Table 3). The 1975 cheatgrass cover in the treated plots, 10 to $16 \%$, was significantly higher than the $7 \%$ cover in the control plots. The percent cover was higher in the clay and straw/clay than the straw treated plots. Due to minimal rainfall no cheatgrass grew in 1977.

The Russian thistle cover was generally $<10 \%$ even though the frequency of occurrence was high during 1975 and 1976. There was a slight increase in Russian thistle cover in the 1977 growing season, probably because of the lack of competition from cheatgrass. Rye, bursage and tansy mustard were present but their covers were minimal.

The biomass of five plant species was measured in 1975 (Table 4). Total biomass from the control plots $\left(19 \mathrm{~g} / \mathrm{m}^{2}\right)$ was approximately one third of the biomass from the treated plots. The biomass in the straw/clay plots was slightly higher than the biomass from the other treated plots. The volunteer rye contributed nearly half the total biomass in the straw treated plots, but the effect of the yield in the straw/clay plots was less. The cheatgrass biomass in straw/clay and clay treated plots were the same. The biomass $\left(<5 \mathrm{~g} / \mathrm{m}^{2}\right)$ of Russian thistle was similar in all plots. A trace of tumble mustard (Sisymbrium altissimum) was measured in the straw/clay plots.

Chemical analysis showed that leaf tissue of the cheatgrass from the plots was $>4 \% \mathrm{~N}$. This amount of $\mathrm{N}$ was adequate for growth of cheatgrass and is in excess of the $0.64 \%$ leaf tissue $N$ that is considered limiting to growth by $\mathrm{Cl}$ ine and Rickard (1973). Tissues from plants of the control plots contained $0.6 \% P$ while those from the clay treated plots had $0.2 \% P$ indicating the bentonite clay treatment may have reduced the availability of soil $P$ for plant uptake (Table 5).

The length, width and height measurements of Russian thistle plants, taken at the end of 1976 growing season, were nearly the same for plants from the control and straw treated plots, but $\sim 30 \%$ smaller in the straw/clay plots (Table 6). Volume measurements of Russian thistle from the clay treated plots were $\sim 30 \%$ greater than those taken from the control and straw 
TABLE 3. Percent Cover Measurements for Three Growing Seasons - 1975, 1976, and 1977

Treatment

\begin{tabular}{|c|c|c|c|c|c|}
\hline \multirow{2}{*}{ Species } & & & & & \\
\hline & Control & Straw & Straw/Clay & & Clay \\
\hline \multicolumn{6}{|l|}{1975} \\
\hline Cheatgrass & $7.0 \pm 1.5$ & $10.3 \pm 0.5^{\star \star}$ & $16.2 \pm 0.6^{\star \star \star}$ & 16.1 & $\pm 2.2^{\star \star \star}$ \\
\hline Rye & 0 & $5.4 \pm 0.7$ & $4.3 \pm 0.5$ & 0 & \\
\hline $\begin{array}{l}\text { Russian } \\
\text { Thistle }\end{array}$ & $4.8 \pm 0.7$ & $6.1 \pm 0.6$ & $7.2 \pm 1.2$ & 4.4 & \pm 0.9 \\
\hline Bursage & $0.7 \pm 0.1$ & $0.7 \pm 0.3$ & $0.5 \pm 0.1$ & 0.4 & \pm 0.1 \\
\hline Tota1 & 12.5 & 22.5 & 28.2 & 20.9 & \\
\hline \multicolumn{6}{|l|}{1976} \\
\hline Cheatgrass & $34.5 \pm 9.6$ & $56.0 \pm 7.5^{\star}$ & $54.3 \pm 9.3^{\star}$ & 59.0 & $\pm 4.7^{\star \star}$ \\
\hline Rye & 0.4 & 1.8 & 0.5 & 0 & \\
\hline $\begin{array}{l}\text { Russian } \\
\text { Thistle }\end{array}$ & 6.0 & 8.1 & 6.1 & 3.6 & \\
\hline Bursage & 0.3 & 0 & 0.5 & 0.6 & \\
\hline $\begin{array}{l}\text { Tansy } \\
\text { Mustard }\end{array}$ & 0.7 & 1.5 & 0.6 & 0.8 & \\
\hline Total & 41.7 & 67.4 & 62.0 & 64.0 & \\
\hline \multicolumn{6}{|l|}{1977} \\
\hline Cheatgrass & $0.1 \pm 0.05$ & $0.1 \pm 0.07$ & 0 & 0 & \\
\hline $\begin{array}{l}\text { Russian } \\
\text { Thistle }\end{array}$ & $13.2 \pm 3.6$ & $16.1 \pm 0.6$ & $8.5 \pm 2.1$ & 12.9 & \pm 2.4 \\
\hline Bursage & $0.2 \pm 0.08$ & $0.2 \pm 0.07$ & $0.2 \pm 0.05$ & 0.1 & \pm 0.05 \\
\hline $\begin{array}{l}\text { Tansy } \\
\text { Mustard }\end{array}$ & $0.1 \pm 0.1$ & $0.1 \pm 0.06$ & 0 & 0.03 & \pm 0.03 \\
\hline Tota 1 & 13.6 & 16.5 & 8.7 & 13.1 & \\
\hline
\end{tabular}

Significantly different from the control $* \alpha \leq 0.2$
$* * \alpha \leq 0.1$
$* \star \star \alpha \leq 0.05$
$* \star * * \alpha \leq 0.01$ 
TABLE 4. Biomass $\left(\mathrm{g} / \mathrm{m}^{2} \pm \mathrm{SE}\right)$ Summary by Species from the Treatments of Straw, Clay, Straw/Clay, and Control. Harvest Date 5/12/75.

Soil Treatments

\begin{tabular}{|c|c|c|c|c|}
\hline Plant Species & Control & Straw & Straw/Clay & Clay \\
\hline Cheatgrass & $16.7 \pm 4.6$ & $25.0 \pm 4.9 \mathrm{NS}$ & $56.0 \pm 7.3^{*}$ & $53.3 \pm 6.9^{*}$ \\
\hline Rye & 0 & $27.6 \pm 16.2$ & $10.0 \pm 4.2$ & 0 \\
\hline Russian Thistle & $1.4 \pm 0.6$ & $4.6 \pm 0.2$ & $1.4 \pm 0.4$ & $1.2 \pm 0.9$ \\
\hline Bursage & $0.9 \pm 0.6$ & 0 & $0.9 \pm 0.6$ & $0.7 \pm 0.6$ \\
\hline Tumble Mustard & 0 & 0 & $\leq 0.1$ & 0 \\
\hline Total & $19.0 \pm S E$ & $57.2 \pm S E$ & $68.4 \pm S E$ & $55.2 \pm S E$ \\
\hline
\end{tabular}

NS Not significantly different

* Significantly different from control $\alpha \leq 0.05$

TABLE 5. Chemical Analysis of Young Leaf Tissue of Cheatgrass Harvested on 4/25/75

Soil Treatment

Control

Straw

Straw/Clay

Clay

$\bar{X} \pm S E$

$\frac{\% N}{4.8 \pm 0.2}$
$4.2 \pm 0.1$
$4.2 \pm 0.2$
$4.5 \pm 0.3$

$4.5 \pm 0.3$

$\frac{\% P}{0.6 \pm 0.2}$
$0.4 \pm 0.02$
$0.2 \pm 0.02$
$0.2 \pm 0.04$

$$
\begin{gathered}
\frac{\% K}{3.6 \pm 0.2} \\
3.6 \pm 0.1 \\
3.5 \pm 0.2 \\
2.7 \pm 0.5
\end{gathered}
$$

plots indicating that the clay influenced the germination success of the seeds. The length, width, height and volume measurements for Russian thistle plants in the 1977 growing season are approximately 1/3 lower than the 1976 measurements (Table 7). 

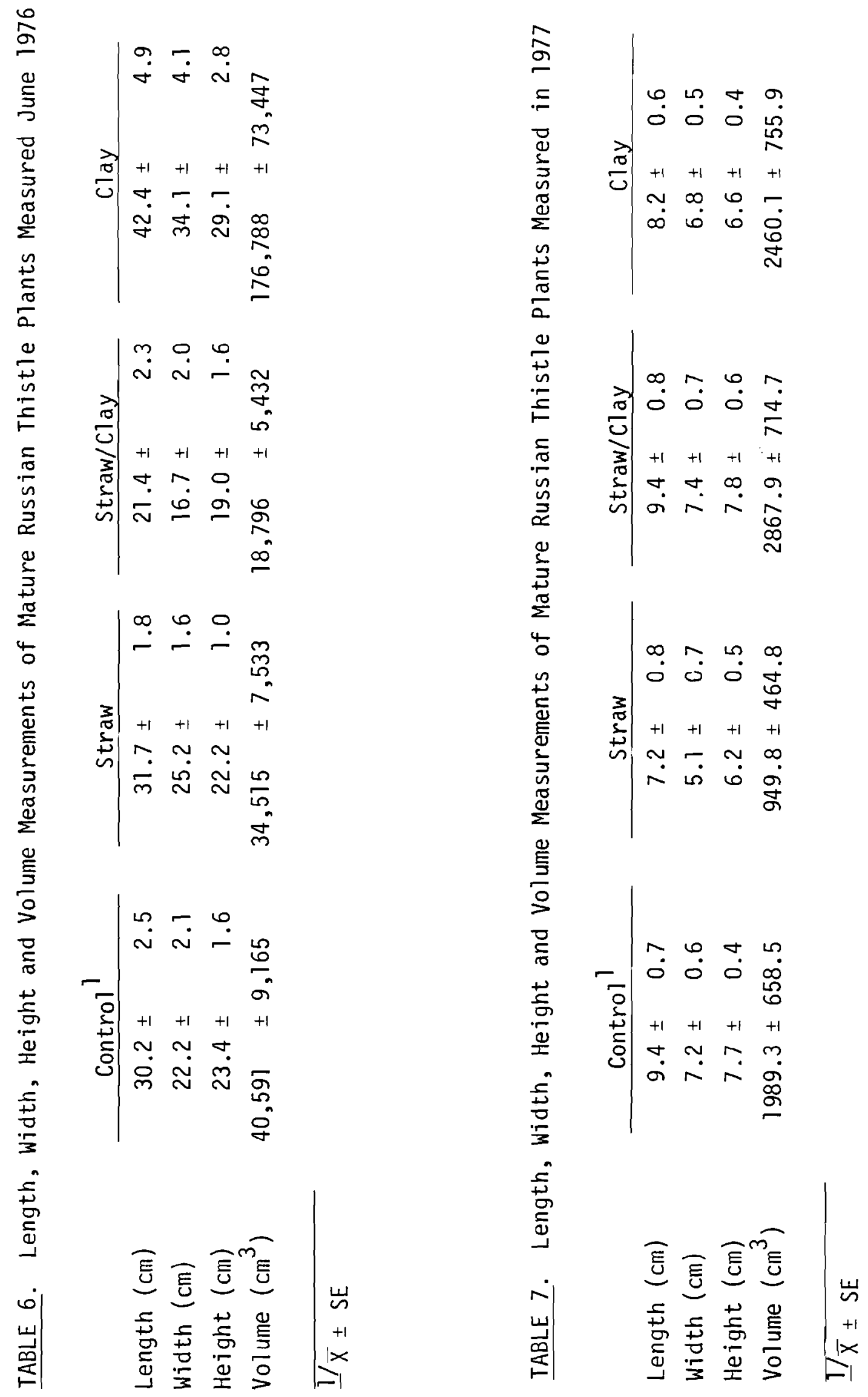
Russian thistle tissues were analyzed for ${ }^{90} \mathrm{Sr}$ to determine if any roots had grown through the uncontaminated soil into the contaminated soil (Table 8). Results show that only one plant from the clay treated plot and one from the straw treated had ${ }^{90} \mathrm{Sr}$ levels ( 15.9 and $17.4 \mathrm{pCi}{ }^{90} \mathrm{Sr} / \mathrm{g}$ ) that were high enough to indicate that these plant roots may have reached the buried pond layer $0.9 \mathrm{~m}$ below surface.

TABLE 8. Strontium-90 Content Measured in Russian Thistle Harvested at the End of the 1976 Growing Season

\begin{tabular}{rlc} 
Plot \# & Treatment & $\mathrm{pCi}^{90} \mathrm{Sr} / \mathrm{g}$ (oven dry) \\
\cline { 1 - 2 } 9 & Contro1 & 0.39 \\
9 & Contro1 & 1.21 \\
12 & Control & 0.09 \\
15 & Control & 0.15 \\
19 & Control & 0.39 \\
2 & Clay & 0.38 \\
11 & Clay & 0.05 \\
14 & Clay & 0.21 \\
17 & Clay & 15.9 \\
20 & Clay & 0.38 \\
3 & Clay/Straw & 0.20 \\
6 & Clay/Straw & 0.74 \\
7 & Clay/Straw & 0.25 \\
10 & Clay/Straw & 0.24 \\
13 & Clay/Straw & 0.15 \\
4 & Straw & 0.33 \\
5 & Straw & 0.58 \\
8 & Straw & 5.01 \\
16 & Straw & 0.45 \\
18 & Straw & 17.40
\end{tabular}


Dietary analysis of black-tailed hare fecal pellets collected from the plots indicate that hares ate a wide variety of grasses and forbs. The major portion of the hare diet in May was comprised of cheatgrass, Siberian wheatgrass (Agropyron sibiricum), needle-and-thread grass (Stipa comata) and Astragalus sp. (Table 9). Lesser quantities of other grasses and forbs also appeared in their diet. Hares ate only small quantities of Russian thistle which agrees with findings from a previous study conducted in the B-C Cribs area (Uresk et a1. 1975).

TABLE 9. Vegetative Composition of Black-Tailed Hare Fecal Pellets Collected on Cover Plots in 1975 and 1976

\begin{tabular}{|c|c|c|c|c|}
\hline \multirow[b]{2}{*}{ Food Species } & \multicolumn{2}{|c|}{$\begin{array}{c}\text { Frequency } \\
\text { of Occurrence }\end{array}$} & \multicolumn{2}{|c|}{ Density } \\
\hline & 1975 & 1976 & 1975 & 1976 \\
\hline \multicolumn{5}{|l|}{ Grasses } \\
\hline Bromus tectorum & 55.1 & 63.7 & 0.80 & 0.93 \\
\hline Agropyron sibiricum & 43.6 & 17.3 & 0.57 & 0.19 \\
\hline Poa sandbergii & 6.8 & 1.0 & 0.07 & 0.01 \\
\hline Secale cereale & 7.4 &.-- & 0.08 & --- \\
\hline Festuca occidental is & 8.4 & --- & 0.09 & --- \\
\hline Stipa comata & 17.9 & 22.0 & 0.20 & 0.25 \\
\hline
\end{tabular}

Forb

Hel ianthus sp.

$2.8 \quad \cdots$

$0.28 \quad---$

Descurainia pinnata

$\begin{array}{ll}1.6 & 0.4\end{array}$

$\begin{array}{ll}0.02 & 0.004\end{array}$

Salsola kali

$0.6 \quad 3.4$

$0.006 \quad 0.03$

Phlox longifolia

$2.3 \quad 0.6$

$0.02 \quad 0.006$

Sitanion hystrix

$3.0 \quad-.-$

0.03

Astragalus sp.

$4.0 \quad 22.2$

$0.04 \quad 0.25$

$\mathrm{ORH}$

--- 9.6

--- 0.1

Lily

-.. 0.2

--- 0.002

Unknown Forb

$0.4 \quad 0.3$

0.003

0.003

Shrub

Artemisia tridentata

$0.1 \quad--$

$0.001 \quad---$ 
Severe wind storms during the 1975-76 season resulted in significant deposition of sand on the windward side of the test plots. This sand cover smothered the cheatgrass. Figure 3 shows the build-up of sand over some of the plot surfaces. The greatest sand deposition (14 cm in depth) occurred next to an untreated disturbed area.

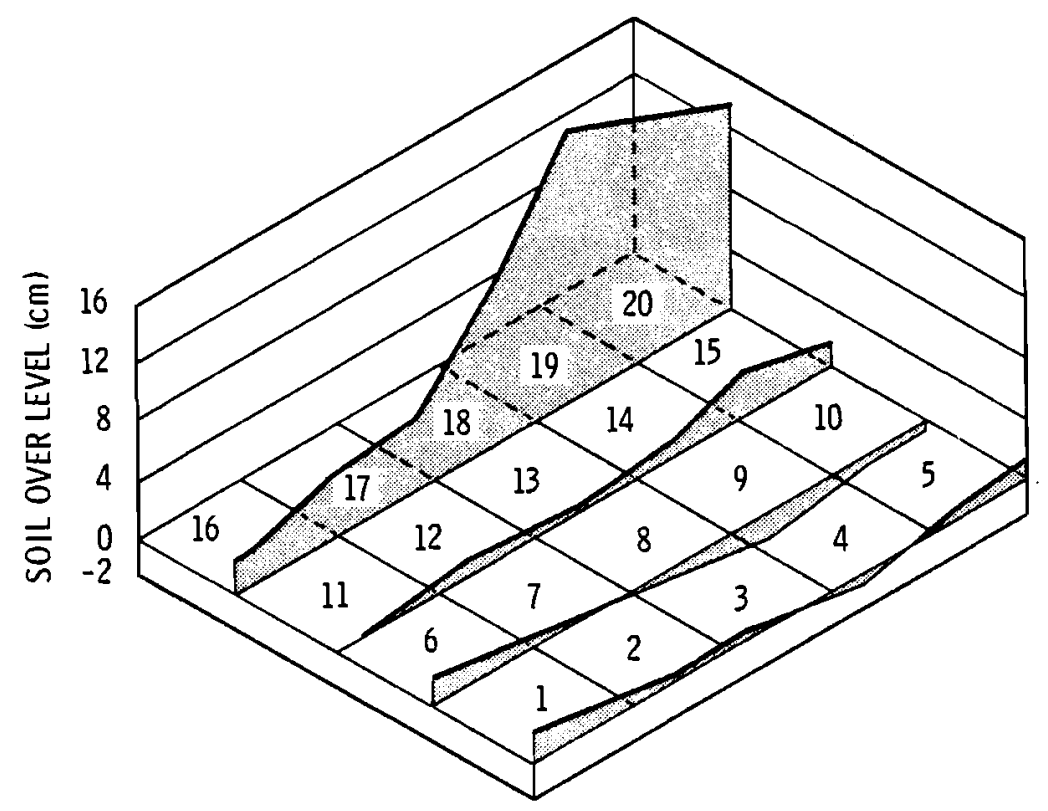

FIGURE 3. Mound of Soil in Centimeters that was Deposited on the Vegetation Plots Numbers 1 Through 20 During 1975 and 1976 Wind Storms

\section{DISCUSSION}

Stands of cheatgrass sufficient to control soil erosion were established during the 1975 and 1976 growing seasons. Enough soil moisture was present during the fall months to germinate the cheatgrass seed and to establish a vegetative cover that could withstand wind erosion. However, in the fall of 1976 and the spring of 1977 there was extremely little rainfall, less than 5 $\mathrm{cm}$ between August and February. This dearth of precipitation was not sufficient to sustain the seedlings once they had germinated. There was enough 
standing and flat litter from the two previous growing seasons to minimize wind erosion on the test site. In March 1977 several rainstorms occurred which prompted germination of considerable numbers of Russian thistle seeds. Most of these seedlings died, with few attaining large size. The dense stand of Russian thistle seedlings, compounded by the lack of soil moisture to sustain the seedling growth, resulted in relatively small plants in 1977 .

The dietary analysis of the black-tailed hare showed that a greater diversity of plants occurred in the hare diet than in the test plots. This indicated that the hare habitat was not restricted to the test area and that they foraged over a larger surrounding area. The finding that the hares consumed large quantities of cheatgrass was different from that found in a study of hare diets in the B-C Cribs area in which cheatgrass did not occur in the diet (Uresk et a1., 1975).

The first necessity in reclaiming or revegetating a disturbed area is control of wind erosion. Until this is accomplished other procedures will be impeded in attempting to stabilize a disturbed area. Straw mulched into the surface layer of soil was effective in controlling wind erosion. However, this treatment is temporary because in approximately 2 yr the straw decays or is blown away. For maximum effectiveness the straw treatment should be used in conjunction with other long-term treatments for stabilizing disturbed areas with a vegetative cover. A bentonite clay treatment is effective in controlling wind erosion but may have some undesirable effects on plant growth. It may be toxic to plant growth if used in too high concentrations. The bentonite caused a reduction of phosphorous content in the leaf tissue and there was evidence that the excess sodium might affect plant growth. If use of clay treatment is desired, the clay could be treated with gypsum or a similar compound to replace the sodium ions with calcium ions making it more compatible with plant nutrient requirements. Treatments using materials other than clay may be more effective and less expensive, because the cost of the bentonite would be approximately $\$ 2000$ per hectare plus the cost of application. 
The data collected during the 3 yr study show the importance of proper timing in the preparation of the seed bed of the area to be stabilized. Fall germinating grasses such as cheatgrass must be planted prior to fall rains or irrigated so that successful germination can be underway before the severe wind storms occur in the late winter and spring months. A vigorous growth of a shallow-rooted, fall-germinating winter annual grass such as cheatgrass should use most of the soil moisture and nutrients prior to the late spring months, thus reducing the germination and growth rate of Russian thistle. Enough litter and standing dead will be produced to restrict soil erosion in dry years when new plant growth is minimized. It is strongly recommended that earth-moving and site preparation activities be completed during late summer and fall. The planting of cheatgrass and other grasses should be completed by october 1 and the soil irrigated to insure that sufficient moisture is available to allow seed germination and growth during the fall and early winter months. Irrigation is recommended because the timing and amount of fall rains are so unpredictable that for many years the rainfall is the 1 imiting factor preventing adequate stands of grass. The addition of nitrogen fertilizer to insure fast-growing healthy plants and sufficient litter production is also recommended. 


\section{REFERENCES}

Cline, J. F. and W. H. Rickard. 1973. "Herbage Yields in Relation to Soil Water and Assimilated Nitrogen." J. Range Mgt. 26:296-298.

Cline, J. F., D. W. Uresk and W. H. Rickard. 1977. "Plants and Soil of a Sagebrush Community on the Hanford Reservation." Northwest Sci. 51:60-70.

Daubenmire, R. 1959. "A Canopy-coverage Method of Vegetation Analysis." Northwest Sci. 33:43-64.

Daubenmire, R. 1970. "Steppe Vegetation of Washington." Wash. Agr. Exp. Station Tech. Bul1. 62:131.

Rogers, L. E. and D. W. Uresk. 1974. "Food Plant Selection by the Migratory Grasshopper (Melanophus sanguinipes) Within a Cheatgrass Community." Northwest Sci. $48: \overline{230-234 .}$

Uresk, D. W., J.F.Cline and W. H. Rickard. 1975. Diets of Black-Tailed Hares on the Hanford Reservation, BNWL-1931 UC-70, Battelle, Pacific Northwest Laboratories, Richland, WA.

Battelle. 1975. BNWL MA-88, Appendix I. Resource book - disposition (DD) of retired contaminated facilities at Hanford, page I.6.45.

Maxfield, H. L. 1977. Personal communication.

Standard Practice Radiochemical Procedures for Offside Environmental Samples, HW-81277 Hanford Laboratories, Hanford Atomic Products Operation, 1964. 


\section{DISTRIBUTION}

No. of

Copies

OFFSITE

A. A. Churm

DOE Chicago Patent Attorney

9800 South Cass Avenue

Argonne, IL 60439

W. A. Osburn

DOE Division of Biomedical

Environmental Research

Washington, DC 20545

J. L. Liverman

DOE Division of Biomedical and

Enviromnmental Research

Washington, DC 20545

J. Swinebroad

DOE Division of Biomedical and

Environmental Research

Washington, DC 20545

R. L. Watters

DOE Division of Biomedical and

Environmental Research

Washington, DC 20545

4 C. W. Kuhlman

DOE Division of Waste Management,

Production and Materials

Management

Washington, DC 20545

G. B. Pleat

DOE Division of Waste Management,

Production and Materials

Management

Washington, DC 20545

D. E. Saire

DOE Division of Waste Management,

Production and Materials

Management

Washington, DC 20545
No. of

Copies

27 U.S. DOE Technical Information Center

Dr. 0. Doyle Markham

Environmental Sciences Branch

Hea 7 th Service Laboratory

U.S. DOE

P.0. Box 2108

Idaho Falls, ID 83401

Dr. Douglas Hunt

Rockwe 11 Internationa 1

Rocky Flats Plant

P.0. Box 464

Golden, CO 80401

Laura King

Washington Public Power Supply Station

Richland, WA 99352

Dr. Mike Smith, Director

Savannah River Ecology Laboratory

Drawer E

Aiken, SC 29801

Dr. F. Ward Whicker

Radiology and Radiation

Biology Department

Colorado State University

Fort Collins, CO 80521

Librarian

Argonne National Laboratory

9800 South Cass Avenue

Argonne, IL 60439

Brookhaven National Laboratory

Research Library

Reference Section

Upton, L.I., NY 11973 
Max Dolance

U.S. DOE Idaho Operations Office Idaho National Engineering Laboratory

EG \& G Idaho, Inc.

P.0. Box 1625

Idaho Falls, ID 83401

E. I. duPont De Nemours and Co.

Aiken

Savannah River Laboratory

Technical Information Service

Room 773-A

Aiken, SC 29801

Lawrence Radiation Laboratory

Lawrence Livermore Laboratory

Technical Information Dept., $L-3$

P.0. Box 808

Livermore, CA 94550

Tom Hakonson

Los Alamos Scientific Laboratory

P.0. Box 1663

Los Alamos, NM 87544

S. I. Auerbach

U.S. DOE Oak Ridge Operations Office

P.0. Box E

Oak Ridge, TN 37830

P. Dunaway

U.S. DOE Nevada Operations Office

P.0. Box 14.100

Las Vegas, NV 89114

\section{ONSITE}

5 U.S. DOE - RL

0. J. Elgert

H. E. Ransom

P.G. Rhoades/P. F. X. Dunigan

F. R. Stranderfer

W. Lei
29 Rockwe 11 Hanford Operations

H. Babad

D. C. Bartholomew

D. J. Brown

R. A. Deju

R. J. Gimera

R. D. Hammond

M. K. Harmon

W. F. Heine

J. E. Kinzer

E. J. Kosiancic

C. W. Manry

G. C. Owens

D. Paine

K. R. Price (10)

J. H. Roecker

J. A. Swenson

V. A. Uresk (3)

D. D. Wodrich

United Nuclear Inc.

T. E. Dabrowski

Westinghouse Hanford Co.

G. D. Carpenter

43 Battelle-Northwest

W. J. Bair

D. A. Cataldo

J. F. Cline (10)

J. P. Corley

L. L. Eberhardt

R. F. Foster

J. J. Fuquay

W. H. Rickard (3)

L. E. Rogers (3)

J. K. Soldat

W. L. Templeton (3)

C. M. Unruh

B. E. Vaughan (5)

Biology Library (3)

Technica T Information (5)

Technical Publications (3) 